Review

\title{
Challenges of Sustainable and Commercial Aquaponics
}

\section{Simon Goddek ${ }^{1,5, \dagger, *}$, Boris Delaide ${ }^{2, \dagger, *}$, Utra Mankasingh ${ }^{3}$, Kristin Vala Ragnarsdottir ${ }^{3,4}$, Haissam Jijakli ${ }^{2}$ and Ragnheidur Thorarinsdottir ${ }^{5}$}

1 Aquaponik Manufaktur GmbH, Gelderner Str. 139, 47661 Issum, Germany

2 Integrated and Urban Plant Pathology Laboratory, Université de Liège, Avenue Maréchal Juin 13, 5030 Gembloux, Belgium; E-Mail: mh.jijakli@ulg.ac.be

3 Institute of Earth Sciences, University of Iceland, Sturlugata 6, 101 Reykjavik, Iceland; E-Mails: utra@hi.is (U.M.); vala@hi.is (K.V.R.)

4 Institute of Sustainability Studies, University of Iceland, Sæmundargata 10, 101 Reykjavik, Iceland

5 Civil and Environmental Engineering, University of Iceland, Taeknigardur, Dunhagi 5, 107 Reykjavik, Iceland; E-Mail: rith@hi.is

$\dagger$ These authors contributed equally to this work.

* Authors to whom correspondence should be addressed; E-Mails: sig97@hi.is (S.G.); boris.delaide@ulg.ac.be (B.D.); Tel.: +354-780-7346 (S.G.); +32-8162-2431 (B.D.).

Academic Editor: Marc A. Rosen

Received: 9 February 2015 / Accepted: 25 March 2015 / Published: 10 April 2015

\begin{abstract}
The world is facing a number of serious problems of which population rise, climate change, soil degradation, water scarcity and food security are among the most important. Aquaponics, as a closed loop system consisting of hydroponics and aquaculture elements, could contribute to addressing these problems. However, there is a lack of quantitative research to support the development of economically feasible aquaponics systems. Although many studies have addressed some scientific aspects, there has been limited focus on commercial implementation. In this review paper, opportunities that have the potential to fill the gap between research and implementation of commercial aquaponic systems have been identified. The analysis shows that aquaponics is capable of being an important driver for the development of integrated food production systems. Arid regions suffering from water stress will particularly benefit from this technology being operated in a commercial environment.
\end{abstract}


Keywords: aquaponics; hydroponics; recirculating aquaculture systems (RAS); phosphorus; nutrient solubilization; $\mathrm{pH}$ stabilization; nutrient cycling; pest management; urban farming; water scarcity

\section{Introduction}

Aquaponics is an integrated multi-trophic system that combines elements of recirculating aquaculture and hydroponics [1], wherein the water from the fish tanks that is enriched in nutrients is used for plant growth. It is a soil-free down-sized natural process that can be found in lakes, ponds and rivers. Using fish waste as fertilizer for crops is an ancient practice. The most well-known examples are the "stationary islands" set up in shallow lakes in central America (e.g., Aztec's Chinampas 1150-1350 BC) [2], and the introduction of fish into paddy rice fields in South-East Asia about 1500 years ago [3]. In the late 70s and early 80s, researchers at the New Alchemy Institute North Carolina State University (USA) developed the basis of modern aquaponics [4]. The probably most known example was set up at the University of the Virgin Islands (UVI) in 1980 [1]. A survey, conducted by Love et al. [4], shows that aquaponics has been receiving growing interest since then [5], which underpins its increasing significance for society as an innovative response for food security.

Its role for food security would be particularly relevant because the global population now exceeds 7.2 billion and is growing rapidly. It is expected to reach 9.6 billion around 2050 with more than $75 \%$ living in urban areas [6]. Urban population growth will require an increasing demand for animal protein [7]. However, the future of conventional farming, including intensive animal protein production, in meeting this demand is challenged by rising but fluctuating energy and oil costs, climate change and pollution. Resource limitations including the decrease of arable surfaces, constrained freshwater supplies, soil degradation and soil nutrient depletion also add to these challenges [8,9]. This alerts researchers to the necessity to compensate existing sustainability deficits in agricultural food systems.

The interlinking of aquacultural and hydroponic procedures allows some of the shortcomings of the respective systems to be addressed, and this represents a promising sustainable food production method. Aquaponics can be considered a sustainable agricultural production system regarding the definition of Lehman et al. [10], who define sustainable agriculture as a process that does not deplete any non-renewable resources that are essential to agriculture in order to sustain the agricultural practices. Francis et al. [11] add that sustainable agricultural production can be achieved by resembling natural ecosystems and "designing systems that close nutrient cycles", which is one of the main characteristics of aquaponics.

Mineral transfers from aquaculture to hydroponics support efficient nutrient recycling, while water recirculation reduces the water use [2]. High yield hydroponic systems require a considerable amount of macro- and micronutrients from industrial and mining origin, leading to high energy (i.e., for production and transport) and finite resources use (e.g., phosphorus and oil) [12-14]. Also, in no-recirculating systems, intermittent disposal of the considerable amounts of nutrient rich water leads to high water consumption as well as surface and groundwater pollution [15]. The regular exchange of water performed in conventional aquacultural systems is not necessary in aquaponics. In this respect, $1 \mathrm{~kg}$ of beef meat requires between 5000 and 20,000 L of water [16] and the same amount of fish bred in semi-intensive 
and extensive conventional aquaculture systems requires a range of 2500-375,000 L [17]. Recirculating aquaculture systems, on the other hand, have a high degree of water reuse (i.e., 95\%-99\%) [18], with water usage down to below $100 \mathrm{~L} \mathrm{~kg}^{-1}$ of fish produced [19]. In aquaponics, nitrate in excess is used for valuable plant production instead of being removed in gaseous form in denitrification units [20].

Although preliminary research has shown that developed aquaponic system components are not yet fully realized in view of either cost effectiveness or technical capabilities [21,22], the aquaponics concept is promising to contribute to both global and urban sustainable food production and should at the same time diminish pollution and need for resources. In order to meet the goal of establishing large-scale eco-efficient and economically viable aquaponic farming projects, this paper reviews the technical and socio-ecological developments that have been undertaken to date and demonstrates which aspects still need to be addressed. The purpose of this paper is to highlight current aquaponics challenges and give directions for further research. For each challenge, various approaches are described.

\section{Principles of Aquaponics}

Aquaponics combines hydroponics and recirculating aquaculture elements. Conventional hydroponics requires mineral fertilizers in order to supply the plants with necessary nutrients but the aquaponics systems use the available fish water that is rich in fish waste as nutrients for plant growth. Another advantage of this combination lies in the fact that excess of nutrients does not need to be removed through periodical exchange of enriched fish water with fresh water as practiced in aquaculture systems. The system results in a symbiosis between fish, microorganisms and plants, and encourages sustainable use of water and nutrients, including their recycling (Figure 1). Within this synergistic interaction, the respective ecological weaknesses of aquaculture and hydroponics are converted into strengths. This combination substantially minimizes the need for input of nutrients and output of waste, unlike when run as separate systems.

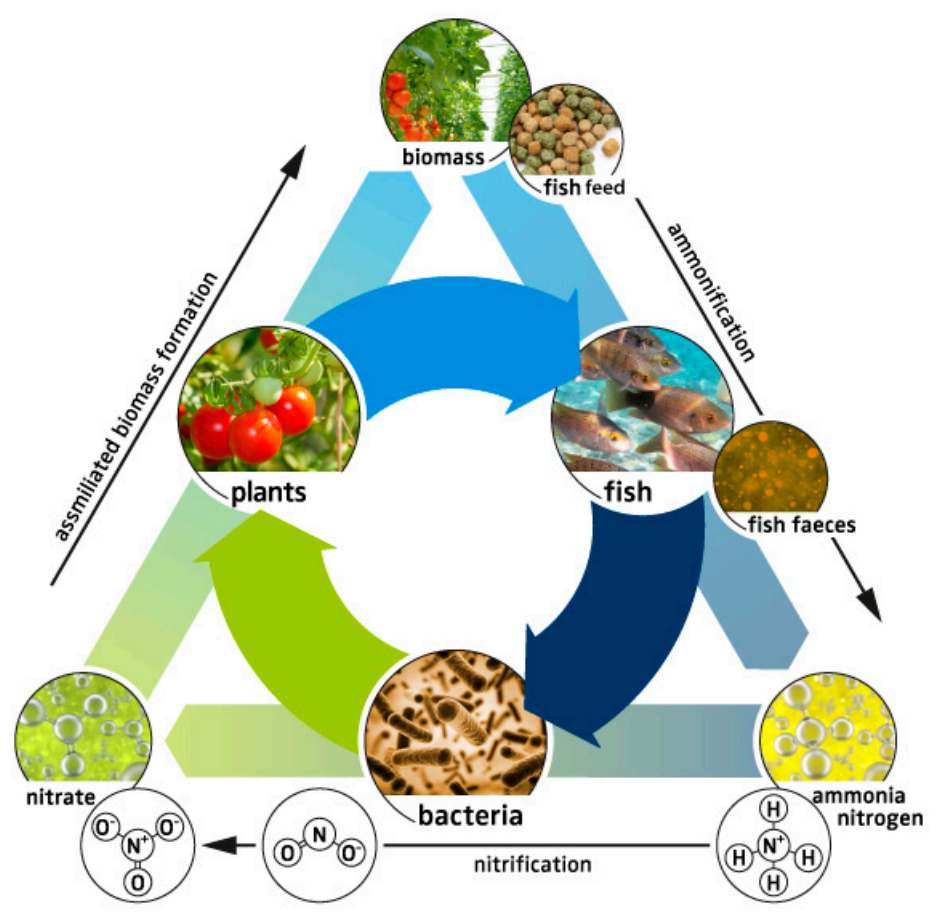

Figure 1. Symbiotic aquaponic cycle. 
Plants need macronutrients (e.g., C, H, O, N, P, K, Ca, S and Mg) and micronutrients (e.g., Fe, Cl, $\mathrm{Mn}, \mathrm{B}, \mathrm{Zn}, \mathrm{Cu}$ and $\mathrm{Mo}$ ), which are essential for their growth. Hydroponic solutions contain well-defined proportions of these elements [23] and are added to the hydroponic solution in ionic form with the exception of $\mathrm{C}, \mathrm{H}$, and $\mathrm{O}$, which are available from air and water. In aquaponics systems, plant nutrient input from the fish tanks contains dissolved nutrient rich fish waste (gill excretion, urine and faeces), comprising of both soluble and solid organic compounds that are solubilized to ionic form in the water and assimilated by the plants. To sustain adequate plant growth the concentrations of micro- and macronutrients need to be monitored. Periodically some nutrients may need to be added to adjust their concentration, for example iron is often deficient in fish waste [24,25].

Aquaponic systems need to be able to host different microorganism communities that are involved in fish waste processing and solubilization. Ammonia $\left(\mathrm{NH}_{4}^{+}\right)$from fish urine and gill excretion can build up to toxic levels if not removed from the system. This can be done by step-wise microbial conversion to nitrate. One of the most important microbial components is the nitrifying autotrophic bacteria consortium that is established as a biofilm on solid surfaces within the system and is principally composed of nitroso-bacteria (e.g., Nitrosomonas sp.) and nitro-bacteria (e.g., Nitrospira sp., Nitrobacter sp.). The ammonia within the system is converted into nitrite $\left(\mathrm{NO}_{2}^{-}\right)$by nitroso-bacteria, before being transformed into nitrate $\left(\mathrm{NO}_{3}{ }^{-}\right)$by the nitro-bacteria [26]. The final product of this bacterial conversion, nitrate, is considerably less toxic for fish and due to its bioconversion, is the main nitrogen source for plant growth in aquaponics systems [27-29]. In most systems, a special biofiltration unit where intensive nitrification occurs is required.

The optimal ratio between fish and plants needs to be identified to get the right balance between fish nutrient production and plant uptake in each system. Rakocy [30] reports that this could be based on the feeding rate ratio, which is the amount of feed per day per square meter of plant varieties. On this basis, a value between 60 and $100 \mathrm{~g} \mathrm{day}^{-1} \mathrm{~m}^{-2}$ has been recommended for leafy-greens growing on raft hydroponic systems [21]. Endut et al. [31] found an optimum ratio of 15-42 grams of fish feed day ${ }^{-1} \mathrm{~m}^{-2}$ of plant growing with one African catfish (Clarias gariepinus) for eight water spinach plants (Ipomoea aquatica). Hence, finding the right balance necessitates fundamental knowledge and experiences with regard to the following criteria: (1) types of fish and their food use rate; (2) composition of the fish food, for example, the quantity of pure proteins converted to Total Ammonia Nitrogen (TAN); (3) frequency of feeding; (4) hydroponic system type and design; (5) types and physiological stages of cultivated plants (leafy greens vs. fruity vegetables); (6) plant sowing density, and (7) chemical composition of the water influenced by the mineralization rate of fish waste. Additionally, since fish, microorganisms and plants are in the same water loop, environmental parameters such as temperature, $\mathrm{pH}$ and mineral concentrations need to be set at a compromise point as close as possible to their respective optimal growth conditions.

\section{System Description}

As outlined above, the aquaponics system can be seen as the connection between a conventional recirculating aquaculture systems (RAS) and hydroponics components. In short, water recirculates in a loop as it flows from the fish tank to filtration units, before it is pumped into the hydroponic beds that are used as water reprocessing units. The filtration units are composed of mechanical filtration units for 
solid particles removal (e.g., drum filter or settling tank), and biofilters for nitrification processes (e.g., trickling or moving bed biofilter). Although system configurations and complexity can vary greatly, Figure 2 illustrates a typical layout.

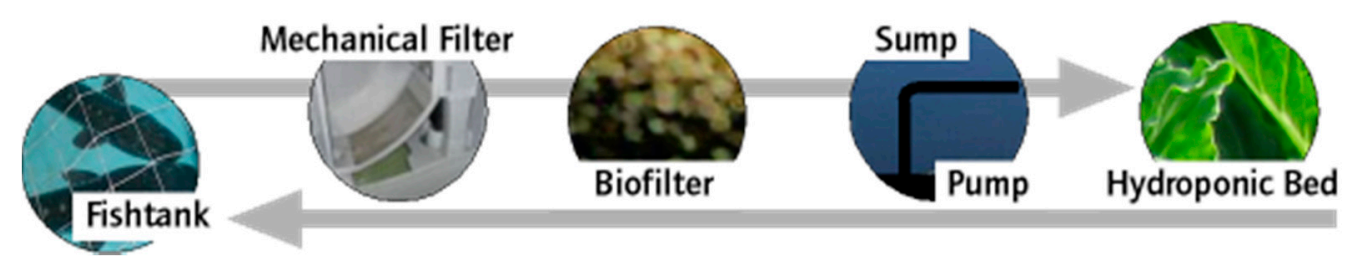

Figure 2. Basic aquaponic system layout.

Three types of hydroponic beds are commonly used: media-based grow bed, Deep Water Culture (DWC) bed, and Nutrient Film Technique (NFT) gutter shaped bed. The media-based grow bed is a hydroponic trough filled with inert substrate (e.g., expanded clay, perlite, pumice, gravel), serving as root support and microbial substrate. The water is commonly supplied in an ebb and flow pattern, ensuring sequential nutrition and aeration. The DWC system consists of large troughs with perforated floating rafts, where net plant pots are inserted. In the DWC system, these plant pots are generally filled with media, such as rockwool, coco or pumice that support the roots, which are then continually submerged in the water tank. The Nutrient Film Technique (NFT) consists of narrow channels of perforated squared pipes where the roots are partially immersed in a thin layer of streaming water. A comparison of the advantages and disadvantages of these hydroponic beds versus soil culture is presented in Table 1.

Table 1. Advantages, disadvantages and nutrient uptake for different grow components in aquaponics with regard to different practical and productivity aspects.

\begin{tabular}{lllll}
\hline \multicolumn{2}{c}{ Media-Based Growing Bed } & \multicolumn{1}{c}{ DWC } & \multicolumn{1}{c}{ NFT } & \multicolumn{1}{c}{ Soil } \\
\hline \multirow{2}{*}{ Advantages } & - Biofiltration: media serves & & - Constant water flow & - Less \\
& as substrate for nitrifying & - Constant & - Small sump & infrastructure \\
bacteria [32]; & water flow; & tank needed; & - Natural roots \\
& - Act as a solids & - Small sump & - Ease of maintenance & environment; \\
& - Mineralization in & tank needed; & and cleaning; & - Colonized by \\
grow bed; & - Ease of & - Require smaller & broad microflora \\
- Colonized by & maintenance and & volume of water; & and fungi [34]; \\
a broad microflora & cleaning [33] & - Light hydroponic & - Accepted as \\
& & & infrastructure, suits & "organic way \\
& & & well for roof farming & of production" \\
\hline
\end{tabular}


Table 1. Cont.

\begin{tabular}{|c|c|c|c|c|}
\hline & Media-Based Growing Bed & $D W C$ & NFT & Soil \\
\hline Disadvantages & $\begin{array}{l}\text { - If flood and drain method: } \\
\text { sizing and reliability plus } \\
\text { large sump tank needed; } \\
\text { - Heavy hydroponic } \\
\text { infrastructure; } \\
\text { - Maintenance and } \\
\text { cleaning difficult; } \\
\text { - Clogging leading to water } \\
\text { channeling, inefficient } \\
\text { biofiltration and inefficient } \\
\text { nutrient delivery to } \\
\text { plants [33] }\end{array}$ & $\begin{array}{l}\text { - Separate } \\
\text { biofilter needs } \\
\text { to be added [32]; } \\
\text { - Require large } \\
\text { volume of water; } \\
\text { - Heavy } \\
\text { hydroponic } \\
\text { infrastructure; } \\
\text { - Device for } \\
\text { roots aeration } \\
\text { mandatory [35] }\end{array}$ & $\begin{array}{l}\text { - Separate } \\
\text { biofilter needed; } \\
\text { - Lower yields } \\
\text { (showed for } \\
\text { lettuce by) [32]; } \\
\text { - Expensive } \\
\text { material; } \\
\text { - the system is } \\
\text { less stable as } \\
\text { there is less } \\
\text { water, }\end{array}$ & $\begin{array}{l}\text { - Small control } \\
\text { on the soil } \\
\text { nutrient solution; } \\
\text { - Good soil } \\
\text { not available } \\
\text { everywhere; } \\
\text { - More vulnerable } \\
\text { for diseases; } \\
\text { - Lower basil and } \\
\text { okra yield than in } \\
\text { aquaponics [29] }\end{array}$ \\
\hline Nutrient uptake & - High & - High & $\begin{array}{l}\text { - Lower } \\
\text { because smaller } \\
\text { root-water } \\
\text { contact area }\end{array}$ & - Lower \\
\hline
\end{tabular}

With respect to a holistic system approach, there are many ways to frame an aquaponic system in terms of hydrological and functional design. A few scientific papers provide working knowledge about different design and key parameters. Table 2 gives an overview of these.

Table 2. Comparison of design and key parameters in well described aquaponic systems found in scientific articles.

\begin{tabular}{|c|c|c|c|c|}
\hline & System A & System B & System C & System D \\
\hline System Type & $\begin{array}{l}\text { Nutrient Film } \\
\text { Technique (NFT) } \\
\text { configured in the conveyor } \\
\text { production system. }\end{array}$ & $\begin{array}{c}\text { Deep Water } \\
\text { Culture (DWC) }\end{array}$ & $\begin{array}{c}\text { Deep Water Culture } \\
\text { (DWC) }\end{array}$ & $\begin{array}{c}\text { Deep Water Culture } \\
\text { (DWC) }\end{array}$ \\
\hline Source & Adler et al. [36] & $\begin{array}{c}\text { Roosta and } \\
\text { Hamidpour [37] }\end{array}$ & Rakocy et al. $[24,38]$ & Endut et al. [39] \\
\hline Location & $\begin{array}{l}\text { The Conservation } \\
\text { Fund's Freshwater } \\
\text { Institute, Shepherdstown, } \\
\text { W. Va., USA }\end{array}$ & $\begin{array}{c}\text { University of } \\
\text { Rafsanjan, Iran }\end{array}$ & $\begin{array}{l}\text { University of Virgin } \\
\text { Islands, USA }\end{array}$ & $\begin{array}{c}\text { University of } \\
\text { Malaysia Terengganu }\end{array}$ \\
\hline Based on & $\begin{array}{l}\text { The system was } \\
\text { theoretically valuated } \\
\text { using data from studies } \\
\text { conducted at the } \\
\text { Conservation Fund's } \\
\text { Freshwater Institute during } \\
1994 \text { and } 1995 \text { [40] }\end{array}$ & UVI-System & $\begin{array}{l}\text { Own setup } \\
\text { (UVI-System) }\end{array}$ & Own Setup \\
\hline $\begin{array}{c}\text { Volume } \\
R A S\left(m^{3}\right)\end{array}$ & $>38$ & 0.848 & 43 & 3 \\
\hline
\end{tabular}


Table 2. Cont.

\begin{tabular}{|c|c|c|c|c|}
\hline & System A & System B & System C & System D \\
\hline $\begin{array}{c}\text { Size } \\
\text { Hydroculture } \\
\left(\mathrm{m}^{2}\right) \\
\end{array}$ & 498 & $\begin{array}{c}\text { Unknown } \\
\text { (consisting of } 8 \text { plants) }\end{array}$ & 220 & 2 \\
\hline $\begin{array}{l}\text { Plant Density } \\
\left(\mathrm{pcs} / \mathrm{m}^{2}\right)\end{array}$ & 5.7 per meter of NFT trays & ND & $\begin{array}{l}8 \text { (basil); } \\
2-4 \text { (okra) }\end{array}$ & ND \\
\hline $\begin{array}{l}\text { Fish Density } \\
\qquad\left(\mathrm{kg} / \mathrm{m}^{3}\right)\end{array}$ & 113.4 & $\begin{array}{c}17.69 \text { (Common Carp), } \\
23.58 \text { (Grass Carp), } \\
17.69 \text { (Silver Carp) }\end{array}$ & $61.5-70.7$ & ND \\
\hline $\begin{array}{c}\text { Daily feed } \\
\text { input/plant } \\
\text { growing area } \\
\left(\mathrm{g} / \text { day } / \mathrm{m}^{2}\right)\end{array}$ & ND & ND & $81.4-99.6$ & $15-42$ \\
\hline $\begin{array}{l}\text { Fish:Plant } \\
\text { Ratio (kg) }\end{array}$ & ND & ND & ND & $1: 8$ \\
\hline Plants Used & $\begin{array}{c}\text { Basil (Ocimum basilicum); } \\
\text { Lettuce (Lactuca sativa L. } \\
\text { "Ostinata") }\end{array}$ & $\begin{array}{c}\text { Tomato (Lycopersicon } \\
\text { esculentum) }\end{array}$ & $\begin{array}{l}\text { Basil (Ocimum } \\
\text { basilicum); Okra } \\
\text { (Abelmoschus } \\
\text { esculentus) }\end{array}$ & $\begin{array}{l}\text { Spinach } \\
\text { (Spinacia } \\
\text { oleracea) }\end{array}$ \\
\hline Fish Used & $\begin{array}{c}\text { Rainbow Trout } \\
\text { (Oncorhynchus mykiss) }\end{array}$ & $\begin{array}{c}\text { Common Carp (Cyprinus } \\
\text { carpio), Grass Carp } \\
\text { (Ctenopharyngodon idella), } \\
\text { Silver Carp } \\
\text { (Hypophthalmichthys } \\
\text { molitrix) } \\
\end{array}$ & $\begin{array}{l}\text { Nile Tilapia } \\
\text { (Oreochromis } \\
\text { niloticus L.) }\end{array}$ & $\begin{array}{l}\text { African } \\
\text { Catfish } \\
\text { (Clarias } \\
\text { gariepinus) }\end{array}$ \\
\hline $\begin{array}{c}\text { Hydroculture } \\
\text { (Wet) Biomass } \\
\left(\mathrm{kg} / \mathrm{m}^{2}\right) \\
\end{array}$ & ND & ND & $\begin{array}{l}2 \text { (basil); } \\
2.9 \text { (okra) }\end{array}$ & 1.16 \\
\hline Biofiltration & $\begin{array}{c}\text { Fluidized Sand Filter + } \\
\text { Carbon Dioxide Strippers }\end{array}$ & Net Filter & Net Filter & $\begin{array}{l}\text { Rapid Sand } \\
\text { Filters } \\
\end{array}$ \\
\hline $\begin{array}{l}\text { Mechanical } \\
\text { Filtration }\end{array}$ & Drum filter & $\begin{array}{c}\text { Clarifier plus Net Plastic } \\
\text { Filter }\end{array}$ & $\begin{array}{c}\text { Clarifier plus } \\
\text { Net Plastic Filter }\end{array}$ & $\begin{array}{l}\text { Rapid Sand } \\
\text { Filters }\end{array}$ \\
\hline $\begin{array}{c}\text { Water } \\
\text { Parameters } \\
\left(\mathrm{pH} ;{ }^{\circ} \mathrm{C}\right) \\
\end{array}$ & pH 7.2; Temp: ND & $\mathrm{pH}$ 7.0-7.7; Temp: $25.7^{\circ} \mathrm{C}$ & $\begin{array}{l}\text { pH 7.0-7.5; } \\
\text { Temp: } 28{ }^{\circ} \mathrm{C}\end{array}$ & $\begin{array}{c}\text { pH 5.6-7.3; } \\
\text { Temp: } \\
27.5-28.8^{\circ} \mathrm{C}\end{array}$ \\
\hline $\begin{array}{c}\text { Temporal } \\
\text { length of } \\
\text { experiment } \\
\end{array}$ & ND & 108 days & $\begin{array}{c}28 \text { weeks (basil); } \\
11.7 \text { weeks } \\
\text { (okra) }\end{array}$ & 35 days \\
\hline $\begin{array}{c}\text { Cost of setup } \\
\text { (\$ U.S.) }\end{array}$ & $\begin{array}{c}\$ 100,120 \\
\text { (hydroponic part) * }\end{array}$ & ND & ND & ND \\
\hline $\begin{array}{l}\text { Cost of annual } \\
\text { running } \\
\text { (\$ U.S.) } \\
\end{array}$ & $\begin{array}{l}\$ 204,040 \text { (lettuce); } \\
\$ 194,950 \text { (basil) }\end{array}$ & ND & $\begin{array}{c}\$ 24,440 \\
\text { (tilapia }+ \text { basil) }\end{array}$ & ND \\
\hline
\end{tabular}


Table 2. Cont.

\begin{tabular}{|c|c|c|c|c|}
\hline & System $A$ & $\begin{array}{c}\text { System } \\
B\end{array}$ & System C & $\begin{array}{c}\text { System } \\
D\end{array}$ \\
\hline $\begin{array}{c}\text { Break-even } \\
\text { price (\$ U.S.) }\end{array}$ & $\begin{array}{c}\$ 13.80 \text { (per box of } 24 \text { lettuces); } \\
\$ 0.53 \text { (per basil plant) }\end{array}$ & ND & $\begin{array}{l}\$ 3.23 \text { (per kg of tilapia); } \\
\$ 1.66 \text { (per kg of basil) }\end{array}$ & ND \\
\hline $\begin{array}{c}\text { Potential annual } \\
\text { profit (\$ U.S.) }\end{array}$ & $\begin{array}{c}\$ 12,350-\$ 44,350 \text { (for box } \\
\text { of } 24 \text { lettuces sold at } \$ 14-\$ 16 \text { ); } \\
\$ 27,750-\$ 66,090 \text { (for basil plant } \\
\text { sold at } \$ 0.60-\$ 0.70 \text { ) }\end{array}$ & ND & $\begin{array}{c}\$ 116,000 \text { (for tilapia sold at } \\
\$ 5.50 / \mathrm{kg} \text { and basil sold at } \\
\$ 22.50 / \mathrm{kg} \text { ) }\end{array}$ & ND \\
\hline
\end{tabular}

* Economic analysis is only about the hydroponic part; ND: Not described in the source.

With respect to Table 2, it is particularly noticeable that DWC systems are mainly used, and important design parameters such as fish to plant ratio or daily feed input are sometimes missing from the literature. It must be mentioned that some costs (i.e., labor costs) are not taken into account, so the financial viability can only be partially estimated.

Apart from the UVI system, there is a lack of scientific literature when it comes to aquaponic experiments on large scale and during long time sequences. Moreover, many experimental setups published are small-scale replicates of the UVI design. Limited data on cost and potential profit of such systems are available $[24,39,41,42]$. As aquaponics is still in a maturing experimental phase, scientific research has focused more on technical aspects than economic viability. However, economic challenges need to be addressed. Experiments covering bigger production systems exist, but they are performed by private research centers or companies, whereby confidential findings are not always made accessible to third parties.

\section{Technical Challenges}

Aquaponics system design and application can be considered a highly multidisciplinary approach drawing from environmental, mechanical and civil engineering design concepts as well as aquatic and plant related biology, biochemistry, and biotechnology. System specific measurements and control technologies also require knowledge of subjects related to the field of computer science for automatic control systems. This high level of complexity necessarily demands in-depth knowledge and expertise of all involved fields. The biggest challenge in commercial aquaponics is its multi-disciplinarity, needing further expertise in economics, finance and marketing. Thus, a high degree of field-specific insight in terms of both practical and in-depth theoretical knowledge is required. This leads to an increasing level of complexity, which directly affects the efficiency factors of the running system. In the interest of highest efficiency and productivity, some numerical trade-offs are recommended and are outlined below. They include $\mathrm{pH}$ stabilization, nutrient balance, phosphorus, and pest management.

\section{1. pH Stabilization}

A crucial point in aquaponic systems is the $\mathrm{pH}$ stabilization, as it is critical to all living organisms within a cycling system that includes fish, plants and bacteria. The optimal $\mathrm{pH}$ for each living component is different. Most plants need a pH value between 6 and 6.5 in order to enhance the uptake of nutrients. The fish species Tilapia (Oreochromis) is known to be disease-resistant and tolerant to large fluctuations 
in $\mathrm{pH}$ value with a tolerance between $\mathrm{pH} 3.7$ and 11, but achieves best growth performance between pH 7.0 and 9.0 [43]. The nitrifying bacteria have a higher optimum pH, which is above 7. Villaverde [44] observed that nitrification efficiency increased linearly by $13 \%$ per $\mathrm{pH}$ unit within a $\mathrm{pH}$ range between 5.0 and 9.0 with the highest activity of ammonium oxidizers at 8.2. Similar observations were made by Antoniou et al. [45], who report the overall nitrification $\mathrm{pH}$ of approximately 7.8. There are three major bacteria, for which optimal $\mathrm{pH}$ conditions are as follows: (1) Nitrobacter: 7.5 [46]; (2) Nitrosomonas: 7.0-7.5 [47], and (3) Nitrospira: 8.0-8.3 [48].

Based on these data, the highest possible $\mathrm{pH}$ value should be consistent with the prevention of ammonia accumulation in the system. Then, the ideal $\mathrm{pH}$ value for the system is between 6.8 and 7.0. Although root uptake of nitrate raises $\mathrm{pH}$ as bicarbonate ions are released in exchange [49], the acidity producing nitrification process has a higher impact on the overall system $\mathrm{pH}$, leading to a constant and slight decrease in the $\mathrm{pH}$-value. There are two approaches to counteract that trend:

(1) Nutritional supplementation is the most applied method in use. By adding carbonate, bi-carbonate or hydroxide to the system, the $\mathrm{pH}$ value can temporarily be adjusted in line with the requirements. Also, they increase the alkalinity parameter that prevents large fluctuations in $\mathrm{pH}$ and thus keeps the system stable. The buffers should preferably be based on calcium, potassium, and magnesium compounds, since they compensate for a possible nutritional deficiency of those essential nutrients for plants [30]. Regarding the composition of the supplementation, it is important to seek a balance between those three elements.

(2) A proposed alternative approach is the implementation of the fluidized lime-bed reactor concept [50] into the field of aquaponics. This water neutralization concept consists of the controlled addition of dissolved limestone $\left(\mathrm{CaCO}_{3}\right)$ to the acid water that leads to a continuous $\mathrm{pH}$-elevating effect due to carbonate solubilization that releases hydroxide anions $\left(\mathrm{OH}^{-}\right)$.

$$
\mathrm{CaCO}_{3}(\mathrm{~s}) \rightleftharpoons \mathrm{Ca}^{2+}+\mathrm{CO}_{3}^{2-}
$$

Depending on $\mathrm{pH}$, when $\mathrm{CaCO}_{3}$ dissolves, some carbonate hydrolyses produce $\mathrm{HCO}_{3}{ }^{-}$

$$
\mathrm{CO}_{3}{ }^{2-}+\mathrm{H}_{2} \mathrm{O} \rightleftharpoons \mathrm{HCO}_{3}-+\mathrm{OH}^{-}
$$

The degree to which the $\mathrm{pH}$ is raised is dependent on the adjustable flow rate. However, this concept requires preliminary empirical measurements with respect to the system's steady pH-drop in order to determine the size of the lime-bed reactor taking the specific flow-rate into consideration.

\subsection{Nutrient Balance}

As an innovative sustainable food production system, the challenge in aquaponics is to use the nutrient input efficiently, minimizing its discard and tending to a zero-discharge recirculating system $[51,52]$. Fish feed, the main nutrient input, can be divided into assimilated feed, uneaten feed, and soluble and solid fish excreta [53]. Soluble excreta are mainly ammonia and is the most available mineral until it is successively transformed into nitrite and nitrate by nitrifying bacteria [54,55]. Both uneaten feed and solid faeces need to be solubilized from organic material to ionic mineral forms that are easily assimilated by plants. Minerals have different solubilization rates and do not accumulate equally [25,33], which influences their concentrations in the water. All involved microorganisms and chemical and physical mechanisms of solubilization are not well understood [20,56]. Under current practices in RAS, 
the solid wastes are only partially solubilized as they are mechanically filtered out on a daily basis [57]. These filtered wastes can be externally fully mineralized and reinserted into the hydroponic beds.

Given the objective of obtaining a low environmental footprint, a zero-discharge recirculating system concept should be achievable according to Neori et al. [52], but more research needs to be carried out on fish waste solubilization with the objective to transform all added nutrients into plant biomass. There are two methods for mineralizing organic material that could be implemented: (1) anoxic digestion in special mineralization or settling units using bioleaching abilities of heterotrophic bacteria (e.g., Lactobacillus plantarum) [58]; and/or (2) using earthworm species such as Lumbricus rubellus capable of converting organic wastes to water enriching compounds in wet composting or grow beds [59]. Vermiculture can facilitate a high degree of mineralization as worm casts contain micro- and macronutrients broken down from organic compounds [60,61]. Addition of external sources (e.g., food waste) of feed for the worms to provide the aquaponic system with additional organic fertilizers has also been suggested [62].

Feed composition directly affects the nutrient excretion by fish, consequently affecting the water chemistry $[33,63]$. One challenge is to find the right fish feed composition for aquaponics in order to attain a water composition that is as close as possible to hydroculture requirements. There is a need to establish the macro- and micronutrient proportion that fish can release in the water for a given feed in a given system; this depends on fish species, fish density, temperature, and type of plants (i.e., fruity plants or leafy greens). This will allow prediction of the subsequent mineral addition needed to match optimal plant growth requirements. Inorganic mineral input adds extra cost and issues for sustainable resource management (e.g., global P peak production reality) [12-14,64]. Thus, fish feed composition should be adapted to minimize this mineral addition while ensuring required nutrition properties for fish yield and avoiding phytotoxic mineral accumulation (e.g., Na). The fish feed origin regarding its environmental footprint should also be taken into account. Low trophic fish species should be preferred and alternative production solutions should be promoted such as human food waste recycling [65], insects, worms, aquatic weed, and algae as a feed base [66,67]. Also, some fish-plant couples might be more appropriate than others in terms of overlap between nutrients profiles offered by excreta and nutrient profiles demanded by plants. Identifying these couples would assure an optimum use of the available nutrients.

A comparison of mineral concentrations in the published aquaponics literature (Table 3), with recommended recirculating hydroponics solutions leads to two main observations: (1) there is a lack of aquaponic data for some macro- and micro-elements, indicating the necessity of more research focus on them; (2) for the available data, the aquaponic concentrations are below the recommended hydroponic level. However, Rakocy and Lennard (pers. comm.) report that hydroponics and aquaponics nutrient solutions are not comparable for many reasons. The nature of the total dissolved solid (TDS) is not the same in these systems. In hydroponics, TDS consists mainly of mineral compounds, while in aquaponics it includes organic molecules wherein nutrients can be locked up and overlooked by measuring procedures such as electrical conductivity (EC) or aqueous sample filtration. Both aqueous sample filtration and the EC measurement methods only take nutrients that are available in ionic form into account. These suspended organic solids are assumed to promote growth because they might simulate natural growing conditions as found in soil, unlike the growing environment of hydroponics [68]. 
Table 3. Comparison of $\mathrm{pH}$ and nutrient concentrations in hydroponic and aquaponic solution for different plant species, all nutrients reported in mg $\mathrm{L}^{-1}$.

\begin{tabular}{|c|c|c|c|c|c|c|c|c|c|c|c|c|c|c|c|c|c|c|}
\hline Plant Species & System & pH & $\mathbf{C a}$ & Mg & $\mathrm{Na}$ & $\mathbf{K}$ & TAN & $\mathrm{NO}_{3}-\mathrm{N}$ & $\mathbf{P O}_{4}-\mathrm{P}$ & $\mathrm{SO}_{4}-\mathrm{S}$ & $\mathbf{C l}$ & $\mathrm{Fe}$ & Mn & $\mathrm{Cu}$ & $\mathbf{Z n}$ & B & Mo & Source \\
\hline Lettuce (Lactuca sativa) & Hydroponic & $5-6.2$ & 180 & 24 & & 430 & 18 & 266 & 62 & 36 & & 2.2 & 0.3 & 0.05 & 0.3 & 0.3 & 0.05 & $\begin{array}{c}\text { Sonneveld and } \\
\text { Voogt, } 2009 \text { [69] }\end{array}$ \\
\hline Lettuce (Lactuca sativa) & Hydroponic & & 200 & 50 & $50-90$ & 210 & & 190 & 50 & 66 & $65-253$ & 5 & 0.5 & 0.15 & 0.15 & 0.3 & 0.05 & Resh, 2012 [23] \\
\hline Lettuce (Lactuca sativa) & Aquaponic & 8 & & & & 48 & & 20 & 10 & & & & & & & & & $\begin{array}{l}\text { Al-Hafedh et al., } \\
2008[70]\end{array}$ \\
\hline Lettuce (Lactuca sativa) & Aquaponic & & 180 & 44 & 17 & 106 & & 137 & 9 & & & & & & & & & $\begin{array}{c}\text { Pantanella et al., } \\
2012[71]\end{array}$ \\
\hline $\begin{array}{c}\text { Basil (Ocimum basilicum } \\
\text { 'Genovese') }\end{array}$ & Aquaponic & 7.4 & 12 & 7 & & 45 & 2.20 & 42 & 8 & & & 2.5 & 0.8 & 0.05 & 0.44 & 0.19 & 0.01 & $\begin{array}{c}\text { Rakocy et al., } \\
2004 \text { [24] }\end{array}$ \\
\hline $\begin{array}{c}\text { Water spinach } \\
\text { (Ipomoea aquatica) }\end{array}$ & Aquaponic & $5.6-$ & & & & & & 20 & 17 & & & & & & & & & Endut et al.. 2010 [31] \\
\hline Tomato (Solanum lycopersicum) & Hydroponic & $5-6.2$ & 110 & 24 & & 254 & 18 & 151 & 39 & 48 & & 0.8 & 0.6 & 0.05 & 0.3 & 0.2 & 0.05 & $\begin{array}{c}\text { Sonneveld and } \\
\text { Voogt, } 2009 \text { [69] }\end{array}$ \\
\hline Tomato (Solanum lycopersicum) & Aquaponic & 7.7 & 34 & & & 27 & 0.33 & 35 & 8 & & & 0.2 & & 0.04 & 0.37 & & & $\begin{array}{c}\text { Roosta and } \\
\text { Hamidpour, } 2011 \text { [37] }\end{array}$ \\
\hline Okra (Abelmoschus esculentus) & Aquaponic & 7.1 & 24 & 6 & 14 & 64 & 1.58 & 26 & 15 & 6 & 12 & 1.3 & 0.06 & 0.03 & 0.34 & 0.09 & 0.01 & $\begin{array}{c}\text { Rakocy et al., } \\
2004[38]\end{array}$ \\
\hline
\end{tabular}


There is a lack of knowledge about the nature of organic molecules and the biochemical processes occurring for their assimilation by plants. Some can be taken up directly or need complex biodegradation to make them available. Another difference is the microflora inherent to aquaponics while sterilization occurs in hydroponics. This microflora can have significant beneficial effects on plant growth and organic molecules' assimilation. Hence, some aquaponics investigators report similar or even better yield than hydroponics for some crops, despite lower concentrations of mineral nutrients [1,71,72-75].

Voogt [76] identifies three aspects of the hydroponic nutrient solution composition that should be taken into account in aquaponics: (1) elemental uptake ratio compared to nutrient composition; (2) ease of uptake of specific elements; (3) the type of growing system that also require a specific nutrient composition. The composition of a nutrient solution must reflect the uptake ratios of individual elements by the crop, otherwise it will lead to either accumulation or depletion of certain elements. As the demand between crops differ, the basic compositions of nutrients solutions are crop specific [77]. The uptake of elements differs widely, the absorption of some can be more difficult and necessitates relatively higher ratios than the straightforward uptake ratio of the crop.

The optimal nutrient levels for leafy and fruity vegetables in aquaponics systems are not yet well established. Additional research should be carried out to assess the optimum value of mineral concentration per single crop or hybrid multi-crop systems regarding growth rate and crop yield. Optimal suspended organic solids' level should be identified with respect to its impact on vegetative growth. Also, a special emphasis should be placed on crop quality since productivity should not be the only argument for competitiveness. For output purposes, this should be compared to (1) hydroponic crop grown with mineral nutrient solution; (2) conventionally soil-based agricultural methods; and (3) organic soil-based agricultural methods. Within-system comparative studies address the productivity, as the macro- and micronutrient composition of the products will play a decisive role with respect to future orientation of healthy and efficient quality food production. A deeper understanding of the biochemical processes occurring in solid fish waste solubilization is necessary with the aim to increase mineral levels in aquaponic water by implementing process and specific waste biofiltration units.

\subsection{Phosphorous}

Among the different minerals, phosphorus (P) deserves a specific attention. It is a macronutrient, which is assimilated by plants in its ionic orthophosphate form $\left(\mathrm{H}_{2} \mathrm{PO}_{4}{ }^{-}, \mathrm{HPO}_{4}{ }^{2-}, \mathrm{PO}_{4}{ }^{3-}\right)$. It is essential for both vegetative and flowering stages of plant growth [78]. In RAS, 30\%-65\% of the phosphorus added to the system via fish feed is lost in the form of fish solid excretion that is filtered out by either settling tanks or mechanical filters [25,79]. Moreover, organic P solubilized as orthophosphate can precipitate with calcium (e.g., hydroxyapatite-Ca5 $\left(\mathrm{PO}_{4}\right)_{3}(\mathrm{OH})$ ) making these elements less available in solution $[25,56]$. Consequently, aquaponic experiments report a range of 1-17 mg L ${ }^{-1} \mathrm{PO}_{4}-\mathrm{P}[24,31,32,38,70,80]$. However, recommended concentrations in standard hydroponics are generally between 40 and $60 \mathrm{mg} \mathrm{L}^{-1} \mathrm{PO}_{4}-\mathrm{P}[23,69,81]$. This discrepancy suggests that phosphate should be added to aquaponic systems, especially for fruity vegetables that do not yet show satisfying yields in aquaponics [82]. Phosphorus is a finite and scarce mining resource and subsequently, an expensive component of hydroponic solutions. Sufficient phosphorus production will certainly be a major concern in the near future $[12,14,64]$. Therefore, solutions to reuse the discharge of P-rich effluents must be explored $[83,84]$. 
As up to $65 \%$ of $\mathrm{P}$ can be wasted in form of aquaculture effluent sludge, recovery solutions should be developed to achieve zero-discharge systems. For example, leachate rich in $\mathrm{P}$ could be obtained by sludge digestion with selected P-solubilizing microorganisms [58] and then reinserted in the hydroponic part of the system. The ultimate objective is to develop a zero-discharge recirculating system with maximum nutrient recycling transformed into plant biomass and improved yield.

\subsection{Pest and Disease Management}

The challenges of pest and disease management is another aspect that needs further improvement [22]. Aquaponic systems are characterized by a broader range of microflora than conventional hydroponic systems, especially because the breeding of fish and biofiltration occurs in the same water loop. Conventional pesticides that are used in hydroponics cannot be used in aquaponics because of toxicity risk to the fish and to the desired biofilm (e.g., autotrophic nitrifying biofilm) [82]. The need to maintain the nitrification biofilm and other nutrient solubilizing microorganisms also prevents the use of antibiotics and fungicides for fish pathogen control and removal in the aquatic environment. Furthermore, antibiotics are not allowed for plant application so their use against fish pathogens must be avoided in aquaponic systems. These constraints demand innovative pest and disease management solutions for fish and plants that minimize impacts on fish and desired microorganisms. Plant and fish pests and pathogens can be divided into four different categories based on specific alternative treatment solutions. These are (1) plant pests - mostly insects that damage the leaves and roots (e.g., aphids, spider mites); (2) plant diseases - microorganisms (e.g., bacteria, fungi) and viruses that attack plants; (3) fish parasites (e.g., monogenea, cestoda); and (4) fish diseases caused by viruses and microorganisms.

Rearing and crop practices that decrease the occurrence of diseases could be applied such as preventive sanitary measures, low density of fish and/or plants, and/or control of environmental conditions, which decrease relative humidity around the plants. In addition to these practices, a few innovative methods of biocontrol already exist for plants cultivated under field or greenhouse conditions. These methods are based on the use of microorganisms with biocontrol activity $[85,86]$, or extracts of such microorganisms or extracts of plants (including essential oils) that show high antimicrobial efficiency and short residence time [87,88]. It will be a challenge to select and adapt these methods to aquaponics systems, considering their compatibility with the other living organisms of the system. Furthermore, microbial diversity can be beneficial for plants. The presence of some mutualistic microorganisms in the plant biosphere can retard the development of pathogens $[34,89,90]$ while promoting growth (e.g., plant growth-promoting rhizobacteria and plant growth-promoting fungi).

Since the presence of a broad range microflora belongs to aquaponic practices, the occurrence of pathogens and risk for human health should also be established, in order to assess the safety of aquaponics and to conduct appropriate quality control. These challenges can lead to the production of products that are quality and pesticide free certified (e.g., organic) and thereby achieve a higher prize in the market and leads to a healthier population [91].

\subsection{Other Technical Challenges}

The regulation of the nitrate level in aquaponics is another challenge. Leafy vegetables need 100-200 mg L ${ }^{-1}$ of $\mathrm{NO}_{3}-\mathrm{N}$ concentration, while fruity vegetables need lower level at species specific 
growth stages [23]. Intermittent intervals of high nitrate can be harmful for fish and nitrate concentration must stay under a certain threshold to avoid adverse physical effects to sensitive species (e.g., 100, 140, $250 \mathrm{mg} \mathrm{L} \mathrm{NO}_{3}-\mathrm{N}$ for Oncorhynchus mykiss, Clarias gariepinus, Oreochromis niloticus, respectively [92-94]). Therefore, it is of particular relevance to determine the best practical means (BPM) fish:plant ratio before setup and/or implement a flow-controlled denitrification unit in the system in order to be able to adjust the desired nitrate level. Some denitrification tanks are already used in RAS [19], however, the technology is not yet fully developed. The approach involves creating anoxic conditions in a column by using the sludge as an organic carbon source for heterotrophic denitrifying microorganisms and recirculates the nitrate-rich water through it. If anoxic conditions are applied in sludge, heterotrophic microorganisms are able to use nitrate instead of oxygen as electron acceptor and reduce it successively to gaseous nitrogen $\left(\mathrm{N}_{2}\right)$ [95]. A critical step is to guarantee additional bio filtration before discharging the treated water back into the system to reduce the risk of toxic $\mathrm{NO}_{2}{ }^{-}$ions from the denitrification process entering the system.

Together with environmental conditions, the population density is the most important parameter for the fish well-being. In outdoor aquaponics facilities such as the UVI system, the common tilapia fish density without use of pure oxygen is around $30-40 \mathrm{~kg} \mathrm{~m}^{-3}$. A higher density up to $60 \mathrm{~kg} \mathrm{~m}^{-3}$ can be achieved in greenhouses [96]; this may be due to more algae and cyanobacteria blooms under longer daylight conditions, producing more oxygen from increased photosynthesis. These characteristics, however, cannot be generalized. In fact, different fish species require different optimal water quality; e.g., warm water species tilapia require a dissolved oxygen (DO) level of 4-6 mg L ${ }^{-1}$, whereas the cold water species trout needs at least $6-8 \mathrm{mg} \mathrm{L}^{-1} \mathrm{DO}$ [97]. Dissolved oxygen is not the only factor that needs to be kept stable. Large fluctuations in temperature and $\mathrm{pH}$ might harm fish, plants, and nitrifying microorganisms $[98,99]$. Despite this fact, temperatures for warm water species such as tilapia and nitrifying bacteria can be $25^{\circ} \mathrm{C}-30{ }^{\circ} \mathrm{C}$, whereas most plants rather prefer colder water temperatures (approx. $20^{\circ} \mathrm{C}-25^{\circ} \mathrm{C}$ ).

Thus far, aquaponics has been built on a trade-off between the needs of fish and plants, respectively. Development is now needed to achieve optimal conditions for both fish and plants with either: (1) emphasis on interdependent parameters of both system components (e.g., combining fish and plant species that preferably require similar environmental conditions within the same range of temperatures and $\mathrm{pH}$ that ensure bacterial nitrification); or (2) the physical separation in two recirculating loops, i.e., an aquaculture and hydroponic loop, described as decoupled systems, where optimal condition for each system is applied with periodic water exchange between them. These are different types of solutions that may contribute to the breakthrough of commercial aquaponics.

\section{Socio-Ecological Challenges}

Aquaponics as such is also responding to diverse ecological and social challenges, which point to the importance to focus on efficient and sustainable forms of agricultural production. Socio-ecological challenges include mineral recycling, water scarcity, energy availability, overfishing, as well as urban farming and short supply chains. They are outlined below. 


\subsection{Mineral Recycling}

In terms of sustainability, both phosphorus and potassium are major components of agricultural fertilizers, and like oil, they are non-renewable resources. Therefore, increasing use and depletion of these minerals without reuse or recapture has a negative impact on and is of significance to their future supply. This in turn would have dramatic consequences for global food security. Nutrient recycling policies, especially for phosphorus, are crucial in order to avoid global food shortages $[12,14]$.

\subsection{Water}

An increasing number of countries are facing economic and physical water scarcity, leading to a growing incapability in feeding their people [100]. On average, global agriculture uses around $70 \%$ of the available freshwater resources. In arid climate zones such as the Middle East and North Africa, the agricultural water consumption can even be up to $90 \%$ [101]. Compared to conventional agriculture, aquaponics uses less than $10 \%$ of water, depending on the climatic conditions [102]. Aquaponics can reduce fresh water depletion associated with irrigation whilst guaranteeing safe encouraging sustainable farming and food production practices, which in turn reduces the freshwater consumption in countries facing water stress. System related water losses that occur in evaporation, plant transpiration and the water content of the agricultural products can be compensated for by capturing water from air humidity [103] or by reverse osmosis desalination plant in coastal areas [104,105].

\subsection{Energy}

The energy requirements of aquaponics are likely to be based on system configuration (design, species, scale, technologies) and geographic location (climate, available resources). For each location, different measures are needed in order to ensure that each system will have a suitable sustainable energy source all year round to provide stable conditions for fish and plants. This is crucial, as fluctuations in temperature might harm fish, plants, and nitrifying microorganisms $[98,99]$. This requirement constitutes a mandatory factor in regions with constantly and seasonally changing climatic conditions as well as in hot and arid climatic zones. Ensuring stable conditions may be achievable in equatorial areas without additional technology. Harnessing solar energy can be beneficial in order to either run climate control systems within greenhouses (e.g., via air conditioning operated by solar photovoltaic modules), or to heat up a low-energy greenhouse with passive solar heating [106]. The latter option is practicable for small sized non-commercial (passive solar) greenhouses, but may not be suitable for larger greenhouses because of the high thermal resistance and high energy losses, associated with medium and large greenhouses. These larger structures may require alternative solutions. In countries such as Iceland and Japan, near-surface geothermal energy can be used by means of heat pumps and direct geothermal heat for maintaining the indoor temperature at the desired level [107,108]. Countries with comparatively unfavorable geological conditions still might assess possible options in terms of using waste heat of combined heat and power (CHP) units to heat the greenhouse during cold days [109] or cool them down during hot days. Those CHP units can mostly be found in combination with agricultural biogas plants, whereby surplus heat is fairly cheap for further disposal. Alternatively, they might consider using fish 
and plant species that are more suitable for the respective climatic conditions in order to avoid the expensive heating or cooling down of the system's water.

\subsection{Overfishing}

Eighty percent of the world's oceans are fully- or over-exploited, depleted or in a state of collapse. One hundred million tons of fish are consumed worldwide each year, providing 2.5 billion people with at least $20 \%$ of their average per capita animal protein intake [110]. Fish is one of the most efficient animal protein producers, with a food conversion ratio (FCR) between 1 and 2 [111]. Since fish demand is increasing whilst the fishing grounds are overexploited [112], aquaculture is the fastest growing sector of world food production [110]. Adverse effects of this development include the high water consumption in case of conventional fish protein production [113], and release of up to $80 \%$ of $\mathrm{N}$ and $85 \%$ of $\mathrm{P}$ per $\mathrm{kg}$ of fish feed [20,79] into the environment. This causes the loss of valuable nutrients, resulting in eutrophication in rivers, lakes and coastal waters, and excessive productivity leading to vast dead zones in the oceans [114]. However, it has to be noted that high-protein fishmeal and fish oil are still key components of aquaculture feeds [115]. Between 2010 and 2012, 23\% of captured fish was reduced to fishmeal and fish oil [115]. Decreasing the proportion of both fishmeal and fish oil in fish feed is thus a challenge that needs to be addressed.

\subsection{Urban Farming and Short Supply Chains}

Aquaponic systems can be set up almost everywhere and have the potential to (sub-)urbanize food production. This could bring important socio-environmental benefits. Aquaponic farming plants could be implemented in old industrial neglected buildings with the advantages of re-establishing a sustainable activity without increasing urbanization pressure on land. Roof gardens would be another possibility, allowing the saving of space in urban areas. If greenhouses are used on roofs, they can insulate buildings while producing food [116]. Another important aspect is minimizing the distance between the food producer and consumer. The longer the supply chain, the more transport, packaging, conservation and labor needed, leading to substantial decreases of resources and energy (e.g., up to 79\% of the retail price in US conventional food distribution [117]). Shortening and simplifying the food supply chains can drastically diminish their environmental impacts, while providing cities with fresher products. This also allows the consumer to clearly identify his food origin [118,119]. Nevertheless, one should not underestimate the development of rural locations, where farmland is plentiful. As aquaponics can be considered a high-tech agricultural method, it is necessary to assure knowledge transfer in this field to maintain skilled labour forces.

\section{Economic Challenges}

The current literature cannot be used to critically assess and predict economic challenges; as presented in Table 2, only two economic sub-studies are available in the peer-reviewed literature [24,36]. At this early stage of scientific research, the main focus has been on technical aspects of aquaponics; financial

figures held by private research entities are not shared with the public. Furthermore, it is difficult to compare the two systems to determine which is better as information may not be available for all system 
parameters and outputs. For example, light intensity $(\mathrm{lm})$ was not reported by Rakocy et al. [24], yet this is one of the major factors affecting plant growth and thus the harvested biomass. Overall, system costs can be measured in the cost per square meter, which is influenced by the complexity of the system and this is closely related to climatic and geographic conditions such as seasonal daylight availability, temperature extremes, and fluctuation of warmth and cold. Also, dynamic costs such as maintenance costs (i.e., price per kWh and labor) and sales revenues in regional markets might differ, making it more difficult to make accurate economic evaluations. Even comparing the most expensive item within a system is difficult, as it differs per region and country (e.g., electricity prices, heat availability, etc.). Consequently, there is no general optimal system, as the system must be adjusted to environmental conditions. Another approach could be to calculate the cost savings by comparing the cost of RAS and hydroponics separately to the same system and integrated to an aquaponic system, under the same environmental and market conditions. Hence, Rupasinghe and Kennedy [120] calculated an improvement of the net present value of $4.6 \%$ in an integrated aquaponic system of lettuce and barramundi. Unfortunately, there are no other studies available for comparison.

Market prices, one of the major factors for profit, can greatly vary between countries for several (e.g., cultural, historical availability) reasons. However, the profit margins will definitely be higher if the product manufacturing costs are low and the food distribution supply chain is short. The transport, packaging and conservation of the food are time and energy consuming, which has an effect on the additional costs and freshness of the products. In order to meet these problems, more urban and peri-urban fresh food production plants need to be implemented to guarantee efficient short food supply chains [119].

Rakocy [21] showed with respect to the crop choice, leafy greens generally achieve a higher profitability than fruity vegetables. In an initial economic analysis, given the University of Virgin Islands (UVI) system design, they had a profit margin with basil exceeding almost by a factor 4 of that of lettuce. This finding should be viewed with a degree of caution because of different domestic market dependencies. Nonetheless, when addressing economic optimization, the three most important factors are: (1) sustainability considerations, which, in the case of aquaponics, are interrelated with economic profits, since the reuse of resources should cut costs for the producer and for the customer; (2) technical optimization of processes (e.g., nutrient availability in different growth stages, nutrient recycling, etc.), and; (3) system components (e.g., design of the hydrological regime, P recycling unit, pH stabilizing reactors, etc.).

Although Vermeulen and Kamstra [22] state that the actual perceived environmental benefits of nutrient reuse, energy efficiency and land use seem only marginally cost-effective, the aspects of possible differences in product quality and societal value are not necessarily reflected in business costs. Also, the use and cost of fertilizers in hydroponic production systems has an increasing importance, as fertilizer costs lie between $5 \%$ and $10 \%$ of the overall costs, and scarce fossil fuels are required in their manufacture [121]. The costing forecasts for fossil fuels could rather exacerbate the situation further and increase the demand of alternative fertilizing solutions such as using waste. Another resource that becomes increasingly scarce is fresh water. Reprocessing instead of discharging contaminated water will be a big challenge that needs to be met in the future. Taxes for wastewater discharge or strong limitations in discharge by local or national policies might become a factor as all point source discharges are 
regulated by water quality policies. Anticipating this trend will ensure economic and financial advantages with respect to conventional agriculture or hydroponic approaches.

\section{Education as a Necessity}

A broad range of knowledge is required to understand and implement the multidisciplinary concept of aquaponics. From the theoretical perspective, the multidisciplinarity of the field and a lack of training in holistic thinking is a hurdle to fully comprehend the concept of aquaponics covering all interrelating issues. The bundling of field-specific in-depth knowledge is required in order to consolidate available scientific knowledge and evidence. At most universities, the two main disciplines, i.e., hydroponics and aquaculture, are either not taught, or offered in different schools, which could complicate access and exchange of knowledge. In practice, aquaculture and hydroponic technologies are well-known. The problem lies in the fact that those disciplines need to be connected. This lack of information-sharing shows the necessity for developing an education network dealing with the improvement of the interconnection between (scientific) disciplines involved in this field. Aquaponic stakeholders, including researchers, entrepreneurs and technicians, need to have basic knowledge covering all disciplines that are involved in this field. Furthermore, experts within every connected field are required to address specific issues within theoretical, scientific, financial as well as practical frameworks.

\section{Discussion}

Challenges underlying sustainable socio-ecological, technical and economic factors pertaining to aquaponics are discussed in this paper to demonstrate the need and the means of extensively investing in more research and development and education in the aquaponics sector. Taking these factors into account is necessary because a pure financial perspective faces significant constraints, notably in terms of natural resource scarcity and their long-term economic consequences. The commercial development of socially, ecologically, and environmentally sustainable aquaponic systems confronts several technical challenges that need to be addressed further: (1) improved nutrient solubilization and recovery for a better use of the nutrient input and reducing extra-mineral addition, e.g., phosphorus recycling; (2) adapted pest management; (3) reduce water consumption to a high degree by limiting the need for water exchange; (4) use of alternative energy sources for hot/cold and arid areas (e.g., CHP waste heat, geothermal heat, etc.); and (5) innovative $\mathrm{pH}$ stabilization methods by implementing fluidized lime-bed reactors that have successfully been used in natural waters [50].

All the factors mentioned above require additional attention, because some production parameters still need to be determined and optimized to prepare aquaponics for commercial use as some components and their interactions are not technically mature yet. This cannot be sufficiently achieved without a greater focus on combining existing knowledge of the different involved fields within a scientific and international framework. These aspects are important, as the commercially aligned technology should not be restricted by certain external conditions. Instead, the systems to be developed should be universally applicable, which implies resource-economic (i.e., resource-saving) production systems that can be run in arid, hot, cold, and urban areas or any combination thereof.

Vermeulen and Kamstra [22] report only a marginal cost reduction for environmental benefits of nutrient reuse and energy efficiency when aquaponics is compared to RAS and hydroponics run 
separately. However, this study did not take socio-ecological factors into account, such as operating in a resource (e.g., phosphorous, water) limited world. Energy cost and fertilizer prices are constantly rising and governmental policies encourage reduction of emitted pollution (e.g., tax incentive schemes), so this cost margin benefit of aquaponics is expected to rise. Although the highest financial profit margin has been shown with leafy greens, it is still necessary to determine the purpose and the scale of the respective systems before building them; the needs on a microeconomic level in terms of food self-sufficiency or local food supply might differ from profit-oriented approaches and from country to country.

\section{Conclusions}

Given the fact that aquaponics follows nutrient and water reusing principles, it seems to be a promising solution for sustainable aquaculture and hydroponic practices. However, further research and developments are needed as demonstrated by the challenges described in this paper. These challenges need to be resolved with the aim to establish fully controlled and standardized aquaponic systems that will be easy to handle and economically viable. The competitiveness of the production method depends on technological developments, local markets, and climatic and geographic conditions that need to be assessed and cannot be generalized. Only addressing those factors thoroughly will eventually validate aquaponics as a sustainable food production alternative.

\section{Acknowledgments}

The work was partly supported by the EcoInnovation funded project EcoPonics, by Aquaponik Manufaktur GmbH and the COST Action FA1305: The EU Aquaponics Hub-Realising Sustainable Integrated Fish and Vegetable Production for the EU.

\section{Author Contributions}

Simon Goddek and Boris Delaide both have equally added to the manuscript. They were assisted by the other co-authors in form and content.

\section{Conflicts of Interest}

The authors declare no conflict of interest.

\section{References}

1. Rakocy, J.E. Island Perspectives; Virgin Islands agricultural Experiment Station: Saint Croix, VI, USA, 1989; pp. 5-10.

2. Turcios, A.E.; Papenbrock, J. Sustainable Treatment of Aquaculture Effluents-What Can We Learn from the Past for the Future? Sustainability 2014, 6, 836-856.

3. Coche, A.G. Fish culture in rice fields a world-wide synthesis. Hydrobiologia 1967, 30, 1-44.

4. Love, D.C.; Fry, J.P.; Genello, L.; Hill, E.S.; Frederick, J.A.; Li, X.; Semmens, K. An international survey of aquaponics practitioners. PLoS One 2014, 9, e102662.

5. Diver, S.; Rinehart, L. Aquaponics-Integration of Hydroponics with Aquaculture; ATTRA NCAT: Butte, MT, USA, 2010; p. 28. 
6. UN. Human development report 2013. Available online: http://hdr.undp.org/en/media/HDR 2013_EN_complete.pdf (accessed on 13 August 2014).

7. Alexandratos, N.; Bruinsma, J. WORLD AGRICULTURE TOWARDS 2030/2050: The 2012 Revision; FAO, Agricultural Development Economics Division: Rome, Italy, 2012.

8. Bindraban, P.S.; van der Velde, M.; Ye, L.; van den Berg, M.; Materechera, S.; Kiba, D.I.; Tamene, L.; Ragnarsdottir, K.V.; Jongschaap, R.; Hoogmoed, M.; et al. Assessing the impact of soil degradation on food production. Curr. Opin. Environ. Sustain. 2012, 4, 478-488.

9. Klinger, D.; Naylor, R. Searching for Solutions in Aquaculture: Charting a Sustainable Course. Annu. Rev. Environ. Resour. 2012, 37, 247-276.

10. Lehman, H.; Clark, E.A.; Weise, S.F. Clarifying the definition of Sustainable agriculture. J. Agric. Environ. Ethics 1993, 6, 127-143.

11. Francis, C.; Lieblein, G.; Gliessman, S.; Breland, T.A.; Creamer, N.; Harwood, R.; Salomonsson, L.; Helenius, J.; Rickerl, D.; Salvador, R.; et al. Agroecology: The Ecology of Food Systems. J. Sustain. Agric. 2003, 22, 99-118.

12. Ragnarsdottir, K.V.; Sverdrup, H.U.; Koca, D. Challenging the planetary boundaries I: Basic principles of an integrated model for phosphorous supply dynamics and global population size. Appl. Geochem. 2011, 26, S303-S306.

13. Sonneveld, C.; Voogt, W. Plant Nutrition in Future Greenhouse Production. In Plant Nutrition of Greenhouse Crops; Springer: Heidelberg, The Netherlands, 2009; pp. 393-403.

14. Sverdrup, H.U.; Ragnarsdottir, K.V. Challenging the planetary boundaries II: Assessing the sustainable global population and phosphate supply, using a systems dynamics assessment model. Appl. Geochem. 2011, 26, S307-S310.

15. Gagnon, V.; Maltais-Landry, G.; Puigagut, J.; Chazarenc, F.; Brisson, J. Treatment of hydroponics wastewater using constructed wetlands in winter conditions. Water. Air. Soil Pollut. 2010, 212, 483-490.

16. Institution of Mechanical Engineers (IME). Global Food: Waste Not, Want Not; IME: London, UK, 2013; p. 31.

17. Al-Hafedh, Y.S.; Alam, A.; Alam, M.A. Performance of plastic biofilter media with different configuration in a water recirculation system for the culture of Nile tilapia (Oreochromis niloticus). Aquac. Eng. 2003, 29, 139-154.

18. Dalsgaard, J.; Lund, I.; Thorarinsdottir, R.; Drengstig, A.; Arvonen, K.; Pedersen, P.B. Farming different species in RAS in Nordic countries: Current status and future perspectives. Aquac. Eng. 2013, 53, 2-13.

19. Martins, C.I.M.; Eding, E.H.; Verdegem, M.C.J.; Heinsbroek, L.T.N.; Schneider, O.; Blancheton, J.P.; D'Orbcastel, E.R.; Verreth, J.A.J. New developments in recirculating aquaculture systems in Europe: A perspective on environmental sustainability. Aquac. Eng. 2010, 43, 83-93.

20. Van Rijn, J. Waste treatment in recirculating aquaculture systems. Aquac. Eng. 2013, 53, 49-56.

21. Rakocy, J.E. Aquaponics -Integrating Fish and Plant Culture; Wiley-Blackwell: Hoboken, NJ, USA, 2012; pp. 344-386.

22. Vermeulen, T.; Kamstra, A. The need for systems design for robust aquaponic systems in the urban environment. 2013, 1004, 71-78. 
23. Resh, H.M. Hydroponic Food Production: A Definitive Guidebook for the Advanced Home Gardener and the Commercial Hydroponic Grower; CRC Press: Boca Raton, FL, USA, 2012.

24. Rakocy, J.E.; Shultz, R.C.; Bailey, D.S.; Thoman, E.S. Aquaponic production of tilapia and basil: Comparing a batch and staggered cropping system. Acta Hortic. 2004, 648, 63-69.

25. Damon, E.; Seawright, R.B.; Walker, R.R.S. Nutrient dynamics in integrated aquaculturehydroponics systems. Aquaculture 1998, 160, 215-237.

26. Tyson, R.V.; Simonne, E.H.; Treadwell, D.D.; White, J.M.; Simonne, A. Reconciling pH for ammonia biofiltration and cucumber yield in a recirculating aquaponic system with perlite biofilters. HortScience 2008, 43, 719-724.

27. Endut, A.; Jusoh, A.; Ali, N. Nitrogen budget and effluent nitrogen components in aquaponics recirculation system. Desalin. Water Treat. 2014, 52, 744-752.

28. Graber, A.; Junge, R. Aquaponic Systems: Nutrient recycling from fish wastewater by vegetable production. Desalination 2009, 246, 147-156.

29. Rakocy, J.E.; Masser, M.P.; Losordo, T.M. Recirculating Aquaculture Tank Production Systems: Aquaponics-Integrating Fish and Plant Culture; Southern Regional Aquaculture Center: Stoneville, MS, USA, 2006; pp. 1-16.

30. Rakocy, J.E. Ten Guidelines for Aquaponic Systems. Aquaponics J. 2007, 1, 14-17.

31. Endut, A.; Jusoh, A.; Ali, N.; Wan Nik, W.B.; Hassan, A. A study on the optimal hydraulic loading rate and plant ratios in recirculation aquaponic system. Bioresour. Technol. 2010, 101, 1511-1517.

32. Lennard, W.A.; Leonard, B.V. A Comparison of Three Different Hydroponic Sub-systems (gravel bed, floating and nutrient film technique) in an Aquaponic Test System. Aquac. Int. 2006, 14, 539-550.

33. Rakocy, J.A.; Hargreaves, J.E. Integration of vegetable hydroponics with fish culture: A review. In Techniques for Modern Aquaculture, Proceedings Aquacultural Engineering Conference; Wang, J.K., Ed.; American Society for Agricultural Engineers: St. Joseph, MI, USA, 1993; pp. 112-136.

34. Bulgarelli, D.; Schlaeppi, K.; Spaepen, S.; van Themaat, E.V.L.; Schulze-Lefert, P. Structure and Functions of the Bacterial Microbiota of Plants. Annu. Rev. Plant Biol. 2013, 64, 807-838.

35. Nicola, S.; Hoeberechts, J.; Fontana, E. Ebb-and-Flow and Floating systems to grow leafy vegetables: A review for rocket, corn salad, garden cress and purslane. Acta Hortic 2007, 747, $585-592$.

36. Adler, P.R.; Harper, J.K.; Wade, E.M. Economic analysis of an aquaponic system for the integrated production of rainbow trout and plants. Int. J. 2000, 1, 15-34.

37. Roosta, H.R.; Hamidpour, M. Effects of foliar application of some macro- and micro-nutrients on tomato plants in aquaponic and hydroponic systems. Sci. Hortic. 2011, 129, 396-402.

38. Rakocy, J.E.; Bailey, D.S.; Shultz, R.C.; Thoman, E.S. Update on tilapia and vegetable production in the UVI aquaponic system. In New Dimensions on Farmed Tilapia, Proceedings of the 6th International Symposium on Tilapia in Aquaculture, Manila, Philippines, 12-16 September 2004; Volume 6, pp. 1-15.

39. Endut, A.; Jusoh, A.; Ali, N.; Nik, W.B.W. Nutrient removal from aquaculture wastewater by vegetable production in aquaponics recirculation system. Desalin. Water Treat. 2011, 32, $422-430$. 
40. Adler, P.R.; Summerfelt, S.T.; Glenn, D.M.; Takeda, F. Evaluation of the Effect of a Conveyor Production Strategy on Lettuce and Basil Productivity and Phosphorus Removal from Aquaculture Wastewater. In Recycling the Resource Ecological Engineering for Wastewater Treatment. Proceedings of the Second International Conference; Switzerland. Environmental Research Forum, Ed.; Trans Tech Publications Ltd: Zurich, Switzerland, 1996; pp. 131-136.

41. Adler, P.R.; Harper, J.K.; Takeda, F.; Wade, E.M.; Summerfelt, S.T. Economic Evaluation of Hydroponics and Other Treatment Options for Phosphorus Removal in Aquaculture Effluent. HortScience 2000, 35, 993-999.

42. Love, D.C.; Fry, J.P.; Li, X.; Hill, E.S.; Genello, L.; Semmens, K.; Thompson, R.E. Ommercial aquaponics production and profitability: Findings from an international survey. Aquaculture 2015, 435, 67-74.

43. McAndrew, B.J.; Turner, G.F.; Robinson, R.L.; Beveridge, M.C.M.; Baird, D.J.; Ross, L.G.; Lowe-McConnell, R.H.; Lorenzen, K.; Penman, D.J.; Little, D.C.; et al. Tilapias: Biology and Exploitation; Beveridge, M.C.M., McAndrew, B.J., Eds.; Springer: Heidelberg, The Netherlands, 2000; p. 508.

44. Villaverde, S. Influence of $\mathrm{pH}$ over nitrifying biofilm activity in submerged biofilters. Water Res. 1997, 31, 1180-1186.

45. Antoniou, P.; Hamilton, J.; Koopman, B.; Jain, R.; Holloway, B.; Lyberatos, G.; Svoronos, S.A. Effect of temperature and ph on the effective maximum specific growth rate of nitrifying bacteria. Water Res. 1990, 24, 97-101.

46. Keen, G.A.; Prosser, J.I. Interrelationship between $\mathrm{pH}$ and surface growth of Nitrobacter. Soil Biol. Biochem. 1987, 19, 665-672.

47. Hatayama, R.; Takahashi, R.; Ohshima, M.; Shibasaki, R.; Tokuyama, T. Ribulose-1,5-bisphosphate carboxylase/oxygenase from an ammonia-oxidizing bacterium, Nitrosomonas sp. K1: Purification and properties. J. Biosci. Bioeng. 2000, 90, 426-430.

48. Blackburne, R.; Vadivelu, V.M.; Yuan, Z.; Keller, J. Kinetic characterisation of an enriched Nitrospira culture with comparison to Nitrobacter. Water Res. 2007, 41, 3033-3042.

49. Kaiser, D.E.; Lamb, J.A.; Bloom, P.R. Managing Iron Deficiency Chlorosis in Soybean; Regents of the University of Minnesota: Saint Paul, MN, USA, 2011.

50. Sverdrup, H.; Eklund, H.; Bjerle, I. Kalkning av rinnande vatten-Erfarenheter från en fluidiserad kalkbrunn. Mover. Vatten 1981, 37, 388-394.

51. Gelfand, I.; Barak, Y.; Even-Chen, Z.; Cytryn, E.; van Rijn, J.; Krom, M.D.; Neori, A. A novel zero discharge intensive Seawater recirculating system for the culture of marine fish. $J$. World Aquac. Soc. 2003, 34, 344-358.

52. Neori, A.; Krom, M.D.; van Rijn, J. Biogeochemical processes in intensive zero-effluent marine fish culture with recirculating aerobic and anaerobic biofilters. J. Exp. Mar. Bio. Ecol. 2007, 349, 235-247.

53. Neto, R.M.; Ostrensky, A. Nutrient load estimation in the waste of Nile tilapia Oreochromis niloticus (L.) reared in cages in tropical climate conditions. Aquac. Res. 2013, doi:10.1111/are.12280.

54. Chen, S.; Ling, J.; Blancheton, J.P. Nitrification kinetics of biofilm as affected by water quality factors. Aquac. Eng. 2006, 34, 179-197. 
55. Lekang, O.-I.; Kleppe, H. Efficiency of nitrification in trickling filters using different filter media. Aquac. Eng. 2000, 21, 181-199.

56. Krom, M.D.; Ben David, A.; Ingall, E.D.; Benning, L.G.; Clerici, S.; Bottrell, S.; Davies, C.; Potts, N.J.; Mortimer, R.J.G.; van Rijn, J. Bacterially mediated removal of phosphorus and cycling of nitrate and sulfate in the waste stream of a "zero-discharge" recirculating mariculture system. Water Res. 2014, 56, 109-121.

57. Cripps, S.J.; Bergheim, A. Solids management and removal for intensive land-based aquaculture production systems. Aquac. Eng. 2000, 22, 33-56.

58. Jung, I.S.; Lovitt, R.W. Leaching techniques to remove metals and potentially hazardous nutrients from trout farm sludge. Water Res. 2011, 45, 5977-5986.

59. Bajsa, O.; Nair, J.; Mathew, K.; Ho, G.E. Vermiculture as a tool for domestic wastewater management. Water Sci. Technol. 2003, 48, 125-132.

60. Qi, Y. Vermiculture Technology: Earthworms, Organic Wastes, and Environmental Management. Int. J. Environ. Stud. 2012, 69, 173-174.

61. Torri, S.I.; Puelles, M.M. Use of vermiculture technology for waste management and environmental remediation in Argentina. Int. J. Glob. Environ. Issues 2010, 10, 239-254.

62. Jorgensen, B.; Meisel, E.; Schilling, C.; Swenson, D.; Thomas, B. Developing food production systems in population centers. Biocycle 2009, 50, 27-29.

63. Martins, C.I.M.; Eding, E.H.; Verreth, J.A.J. The effect of recirculating aquaculture systems on the concentrations of heavy metals in culture water and tissues of Nile tilapia Oreochromis niloticus. Food Chem. 2011, 126, 1001-1005.

64. Gilbert, N. Environment: The disappearing nutrient. Nature 2009, 461, 716-718.

65. Amadori, M.; Daley, D. An Engineered Ecosystem for Waste Management and Food Production. Master's Thesis, State University of New York College of Environmental Science and Forestry, Syracuse, NY, USA, 2012; p. 44.

66. Mandal, R.N.; Datta, A.K.; Sarangi, N.; Mukhopadhyay, P.K. Diversity of aquatic macrophytes as food and feed components to herbivorous fish-A review. Indian J. Fish. 2010, 57, 65-73.

67. Van Huis, A. Potential of Insects as Food and Feed in Assuring Food Security. Annu. Rev. Entomol. 2011, 58, 563-583.

68. Böhme, M. Effects of lactate, humate and bacillus subtilis on the growth of tomato plants in hydroponic systems. Acta Hortic. 1999, 481, 231-239.

69. Sonneveld, C.; Voogt, W. Nutrient Management in Substrate Systems. In Plant Nutrition of Greenhouse Crops; Springer: Heidelberg, The Netherlands, 2009; pp. 277-312.

70. Al-Hafedh, Y.S.; Alam, A.; Beltagi, M.S. Food Production and Water Conservation in a Recirculating Aquaponic System in Saudi Arabia at Different Ratios of Fish Feed to Plants. J. World Aquac. Soc. 2008, 39, 510-520.

71. Pantanella, E.; Cardarelli, M.; Colla, G.; Rea, E.; Marcucci, A. Aquaponics vs. Hydroponics: Production and Quality of Lettuce Crop. Acta Hortic. 2012, 927, 887-893.

72. Lennard, W.; Leonard, B. A comparison of reciprocating flow versus constant flow in an integrated, gravel bed, aquaponic test system. Aquac. Int. 2005, 12, 539-553.

73. Nichols, M.; Lennard, W. Aquaponics in New Zealand. Pract. Hydroponics Greenh. 2010, 115, $46-51$. 
74. Savidov, N.A.; Hutchings, E.; Rakocy, J.E. Fish and plant production in a recirculating aquaponic system: A new approach to sustainable agriculture in Canada. 2007, 742, 209-222.

75. Savidov, N. Evaluation and Development or Aquaponics Production and Product Market Capabilities in Alberta. Available online: http://www.ecogrow.ca/pdf/CDC_Report_Phase_II.pdf (accessed on 10 July 2014).

76. Voogt, W. Potassium Management of Vegetables Under Intensive Growth Conditions; Pasricha, N.S., Bansal, S.K., Eds.; The International Potash Institute: Bern, Switzerland, 2002; pp. 347-362.

77. De Kreij, C.; Voogt, W.; Baas, R. Nutrient Solutions and Water Quality for Soilless Cultures; Brochure; Research Station for Floriculture and Glasshouse Vegetables (PBG): Naaldwijk, The Netherlands, 1999; Volume 196.

78. López-Arredondo, D.L.; Leyva-González, M.A.; Alatorre-Cobos, F.; Herrera-Estrella, L. Biotechnology of nutrient uptake and assimilation in plants. Int. J. Dev. Biol. 2013, 57, 595-610.

79. Schneider, O.; Sereti, V.; Eding, E.H.; Verreth, J.A.J. Analysis of nutrient flows in integrated intensive aquaculture systems. Aquac. Eng. 2005, 32, 379-401.

80. Villarroell, M.; Alvarino, J.M.R.; Duran, J.M. Aquaponics: Integrating fish feeding rates and ion waste production for strawberry hydroponics. Spanish J. Agric. Res. 2011, 9, 537-545.

81. Sikawa, D.C.; Yakupitiyage, A. The hydroponic production of lettuce (Lactuca sativa L) by using hybrid catfish (Clarias macrocephalus $\times$ C. gariepinus) pond water: Potentials and constraints. Agric. Water Manag. 2010, 97, 1317-1325.

82. Nichols M.A.; Savidov, N.A. Aquaponics: A nutrient and water efficient production system. Acta Hortic. 2012, 947, 129-132.

83. Cordell, D.; Rosemarin, A.; Schröder, J.J.; Smit, A.L. Towards global phosphorus security: A systems framework for phosphorus recovery and reuse options. Chemosphere 2011, 84, 747-758.

84. Shu, L.; Schneider, P.; Jegatheesan, V.; Johnson, J. An economic evaluation of phosphorus recovery as struvite from digester supernatant. Bioresour. Technol. 2006, 97, 2211-2216.

85. Jijakli, H.M. Pichia anomala in biocontrol for apples: 20 years of fundamental research and practical applications. Antonie Van Leeuwenhoek 2011, 99, 93-105.

86. Saraf, M.; Pandya, U.; Thakkar, A. Role of allelochemicals in plant growth promoting rhizobacteria for biocontrol of phytopathogens. Microbiol. Res. 2014, 169, 18-29.

87. Kouassi, K.H.S.; Bajji, M.; Jijakli, H. The control of postharvest blue and green molds of citrus in relation with essential oil-wax formulations, adherence and viscosity. Postharvest Biol. Technol. 2012, 73, 122-128.

88. Lang, G.; Buchbauer, G. A review on recent research results (2008-2010) on essential oils as antimicrobials and antifungals. A review. Flav. Fragr. J. 2012, 27, 13-39.

89. Fujiwara, K.; Iida, Y.; Iwai, T.; Aoyama, C.; Inukai, R.; Ando, A.; Ogawa, J.; Ohnishi, J.; Terami, F.; Takano, M.; et al. The rhizosphere microbial community in a multiple parallel mineralization system suppresses the pathogenic fungus Fusarium oxysporum. Microbiologyopen 2013, 2, 997-1009.

90. Fujiwara, K.; Aoyama, C.; Takano, M.; Shinohara, M. Suppression of Ralstonia solanacearum bacterial wilt disease by an organic hydroponic system. J. Gen. Plant Pathol. 2012, 78, 217-220.

91. Crinnion, W.J. Organic foods contain higher levels of certain nutrients, lower levels of pesticides, and may provide health benefits for the consumer. Altern. Med. Rev. 2010, 15, 4-12. 
92. Davidson, J.; Good, C.; Welsh, C.; Summerfelt, S.T. Comparing the effects of high vs. low nitrate on the health, performance, and welfare of juvenile rainbow trout Oncorhynchus mykiss within water recirculating aquaculture systems. Aquac. Eng. 2014, 59, 30-40.

93. Schram, E.; Roques, J.A.C.; Abbink, W.; Yokohama, Y.; Spanings, T.; de Vries, P.; Bierman, S.; van de Vis, H.; Flik, G. The impact of elevated water nitrate concentration on physiology, growth and feed intake of African catfish Clarias gariepinus (Burchell 1822). Aquac. Res. 2012, 45, 1499-1511.

94. Webster, C.D.; Lim, C. Tilapia; CRC-Press: Boca Raton, FL, USA, 2008.

95. Kampschreur, M.J.; Temmink, H.; Kleerebezem, R.; Jetten, M.S.M.; van Loosdrecht, M.C.M. Nitrous oxide emission during wastewater treatment. Water Res. 2009, 43, 4093-4103.

96. Losordo, T.M.; Masser, M.P.; Rakocy, J.E. Recirculating Aquaculture Tank Production Systems-A Review of Component Options; Southern Regional Aquaculture Center: Stoneville, MS, USA, 1999.

97. Timmons, M.B.; Ebeling, J.M. Recirculating Aquaculture; 3rd ed.; Ithaca Publishing Company LLC: Ithaca, NY, USA, 2013.

98. Stark, J.M. Modeling the temperature response of nitrification. Biogeochemistry 1996, 35, $433-445$.

99. Zhu, S.; Chen, S. The impact of temperature on nitrification rate in fixed film biofilters. Aquac. Eng. 2002, 26, 221-237.

100. World Water Assessment Programme (WWAP). The United Nations World Water Development Report 4: Managing Water under Uncertainty and Risk; United Nations Educational: Paris, France, 2012; p. 380.

101. FAO. AQUASTAT Survey, Irrigation in Africa in Figures; FAO: Rome, Italy, 2005.

102. Bernstein, S. Aquaponic Gardening: A Step-by-Step Guide to Raising Vegetables and Fish Together; New Society Publishers: Gabriola Island, BC, Canada, 2011; p. 256.

103. Fraunhofer Gesellschaft. Research News; Fraunhofer-Gesellschaft München, Fraunhofer Press: München, Germany, 2009.

104. Duriau, Y. Desalination by reverse osmosis. Desalination 1968, 5, 120-121.

105. Greenlee, L.F.; Lawler, D.F.; Freeman, B.D.; Marrot, B.; Moulin, P. Reverse osmosis desalination: Water sources, technology, and today's challenges. Water Res. 2009, 43, 2317-2348.

106. Chan, H.-Y.; Riffat, S.B.; Zhu, J. Review of passive solar heating and cooling technologies. Renew. Sustain. Energy Rev. 2010, 14, 781-789.

107. Bakos, G.C.; Fidanidis, D.; Tsagas, N.F. Greenhouse heating using geothermal energy. Geothermics 1999, 28, 759-765.

108. Ragnarsson, Á. Utilization of geothermal energy in Iceland. In Proceedings of the International Geothermal Conference, Reykjavík, Iceland, 14-17 September 2003.

109. Ismail, B.; Ahmed, W. Thermoelectric Power Generation Using Waste-Heat Energy as an Alternative Green Technology. Recent Patents Electr. Eng. 2009, 2, 27-39.

110. FAO. Statistical Yearbook; FAO: Rome, Italy, 2012; p. 366.

111. Belal, I.E.H. A review of some fish nutrition methodologies. Bioresour. Technol. 2005, 96, 395-402. 
112. Millennium Ecosystem Assessment. Ecosystems and Human Well-Being: Synthesi; Island Press: Washington, DC, USA, 2005; p. 137.

113. EcoPlan International (EPI). Global Assessment of Closed System Aquaculture; EPI: Vancouver, BC, Canada, 2008; p. 79.

114. Dybas, C.L. Dead Zones Spreading in World Oceans. Bioscience 2005, 55, 552-557.

115. FAO. The State of World Fisheries and Aquaculture; FAO: Rome, Italy, 2014; pp. 1-243.

116. Hui, S.C.M. Green roof urban farming for buildings in high-density urban cities. In Proceedings of the World Green Roof Conference, Hainan, China, 8-21 March 2011; pp. 1-9.

117. Wohlgenant, M.K. Chapter 16 Marketing margins: Empirical analysis. Handb. Agric. Econ. 2001, 1, 933-970.

118. Bon, H.; Parrot, L.; Moustier, P. Sustainable urban agriculture in developing countries. A review. Agron. Sustain. Dev. 2010, 30, 21-32.

119. Toumi, S.; Vidal, R. A Comparison of Urban Agriculture and Short Food Chains in Paris and Tunis. Urban Agric. Mag. 2010, 24, 31-34.

120. Rupasinghe, J.W.; Kennedy, J.O.S. Economic benefits of integrating a hydroponic-lettuce system into a barramundi fish production system. Aquac. Econ. Manag. 2010, 14, 81-96.

121. Hochmuth, G.J.; Hanlon, E.A. Commercial Vegetable Fertilization Principles; \#SL319; Horticultural Sciences Department: Gainesville, USA, 2010; pp. 1-17.

(C) 2015 by the authors; licensee MDPI, Basel, Switzerland. This article is an open access article distributed under the terms and conditions of the Creative Commons Attribution license (http://creativecommons.org/licenses/by/4.0/). 